\title{
Effect of Dividend on Stock Market Price: A Panel Data Approach
}

\begin{abstract}
Dividend policy is major concern for investor, managers and policy makers. Proper dividend policy helps to achieve the wealth maximization goal of the firm. This study has examined the impact of dividend on stock market price of Nepalese enterprises. For this purpose 33 dividend paying companies listed on NEPSE has been selected as sample. Likewise, this study used unbalance panel data for the period of 2000/01 to 2018/19. Breusch and Pagan Lagrangian multiplier test concluded that Pooled regression model is not appropriate and Hausman test concluded that Random Effect model is not appropriate for the data used in this study. Thus, this study adopted Fixed Effect model to analyze the impact of dividend on stock market price. This study concluded that there is significant impact of dividend on stock market price of Nepalese enterprises after controlling return on equity, earnings per share and return on equity. Finally, this study concluded that cash dividend has significant negative and stock dividend has significant positive impact on stock market price of Nepalese enterprises.
\end{abstract}

Key words: Cash dividend, Stock dividend, Stock market price, Nepalese enterprises, Panel data.

\section{Introduction}

Dividend policy is important issue for investor, managers and policy makers. It is important issue for investor because they take dividend not only as the source of income; they also take it as yard stick for making investment decision in any enterprises. The major concern of modern corporate finance is to make sound dividend policy which can attract investors and can increase market value of the firm. Financial manager always wants to maximize the shareholders' wealth. For that purpose they perform so many activities in the organization. One of them is dividend policy. If the organization maintains proper dividend policy they can maximize the shareholders' wealth. Regarding the impact of dividend on the value of the firm Miller and Modigliani (1961) proposed the irrelevancy theory. Miller and Modigliani concluded that dividend has no any significant impact on price of share of firm thus it does not have any effect on shareholders' wealth. They further concluded that the value of firm is determined by the earning power of the firm's investment policy of assets not by dividend policy. On the other hand, Gordon (1963) concluded that dividend is relevant for the value of the firm. Similarly, some of the empirical studies conducted in the developed and developing

* Associate Professor, PhD Scholar, Mid-Western University, Surkhet, Nepal.

Email:purnaman.skt@gmail.com 9858040382 
capital market concluded that dividend makes significant impact on stock market price thus increases the value of firm whereas some empirical studies concluded that there is no significant impact of dividend on stock market price.

In the context of Bangladesh Rashid and Rahman (2008) has analyzed the impact of dividend policy on stock price volatility. After controlling the earnings volatility, payout ratio firm size and growth in assets Rashid and Rahman concluded that dividend yield has insignificant positive impact on stock price volatility. Likewise, using the data for the period of 1996 to 2006; Adesola and Okwong (2009) concluded that traditional factors are significant in explaining and predicting the dividend of Nigerian companies. They further concluded that dividend determines the stock market price of Nigeria companies.

Regarding the impact of dividend policy on stock price risk of Karachi Stock Exchange, Pakistan Asghar, Shah, Hamid and Suleman (2011) has conducted a study. Using the data for the period of 2005 to 2009 they found strong positive correlation of dividend yield with stock price volatility. On the other hand they found strong negative correlation of assets growth rate and stock price volatility. On the other hand Khan (2012) analyzed the effect of dividend announcement on stock price of chemical and pharmaceutical industry of Pakistan. Khan selected twenty nine chemical and pharmaceutical companies listed on KSE-100 Index for the period of 2001 to 2010. Using the Fixed and Random Effect Model on panel data Khan concluded that stock dividend has significant positive impact on stock market price of chemical and pharmaceutical industry of Pakistan after controlling earnings per share, profit after tax and return on equity. Likewise, Khan found a significant positive impact of earnings per share and profit after tax and significant negative impact of retention ratio and return on equity of stock price of chemical and pharmaceutical industry of Pakistan.

In another study, Hashemijoo, Ardekani, and Younesi (2012) has analyzed the relationship between dividend policy and stock price volatility of consumer product companies listed in Malaysian stock market. Hashemijoo et al. has selected 84 consumer product companies listed in main market of Bursa, Malaysia during the period of 2005 to 2010. They used two main measures of dividend policy i. e. dividend yield and dividend payout and size, earning volatility, leverage, debt and growth are used as control variables. Hashemijoo et al. found the significant negative relationship between dividend yield and dividend payout with market price volatility of consumer product companies. Likewise, they found significant negative relationship between size and stock price volatility. In the context of Indonesia, Margaretha (2015) has analyzed the effect of cash dividends per share, retained earnings per share, earnings per share, and leverage on the stock price. Margaretha used the secondary data of 23 manufacturing companies for the period of 2008 to 2012. Margaretha concluded that cash dividends per share, retained earnings per share, earnings per share, and leverage have significant impact on the stock price of manufacturing companies of Indonesia.

The effect of dividend policy on stock price of the stock listed on National Stock Exchange for the period of 2008 to 2017 has analyzed by Singh and Tandon (2019). Singh and Tandon used 
panel data and adopted Pooled, Fixed Effect, Random Effect regression model for analysis. They used Hausman test to select appropriate model and concluded that Random Effect model is appropriate model for analyzing the relationship of these variables. The study of Singh and Tandon found that dividend policy has significant effect on stock market price. They further concluded that earnings per share has significant positive impact and dividend yield, return on equity and profit after tax has significant negative impact on stock market price. Finally, they concluded that dividend per share and retention ratio has no significant impact on stock market price of stock listed on the National Stock Exchange.

In contrast to voluminous studies conducted in foreign contest very few studies have been conducted in Nepalese context and inconclusive conclusion have been drawn. In the context of Nepal, Pradhan (2003) has analyzed the impact of dividend payment and retained earnings on stock market price. Pradhan concluded that stock market price is affected by dividend payments. Further Pradhan pointed out that dividend payment is more important than retained earnings of the form. The study of Pradhan concluded that if the company holds more retained earnings than stock market price may also decline. Similarly, Joshi (2012) has analyzed the impact of dividend on stock price of banking and non-banking sector of Nepal. Joshi used current market price of stock as dependent variable and dividend per share, retained earnings per share, lagged price earnings ratio and lagged market price per share as explanatory variable. Using the multivariate regression analysis Joshi concluded that dividend has more impact than retained earnings on stock price of Nepalese enterprises. Further Joshi found that dividend has significant positive impact on stock market price of banking and non-banking sector of Nepal. On the other hand, Bhattarai (2016) has examined the effect of dividend payment on stock price of Nepalese commercial banks. Using the data of 7 Nepalese commercial banks for the period of 2010 to 2016 Bhattarai found a significant positive impact of dividend on share price. Similarly, Baral and Pradhan (2018) has also analyzed the impact of dividend policy on stock price of Nepalese commercial banks. Baral and Pradhan has selected ten commercial bank listed on Nepal Stock Exchange for the period of 2012/13 to 2016/17. They have included top gainers and top looser bank on the basis of their performance on stock market. Baral and Pradhan concluded that earnings per share and price earnings ratio have significant positive impact on stock price of top gainer commercial banks. On the other hand they concluded that earnings per share, price earnings ratio and dividend per share have significant positive impact on stock price of top looser commercial banks. They further concluded that dividend per share is the strongest factor that affects the stock price of top looser commercial bank.

Empirical studied conducted on different market revealed the inconclusive impact of dividend on stock market price. Thus, this study aims to empirically investigate the impact of dividend on stock market price of Nepalese enterprises. 


\section{Objective of the study}

The main objective of this study is to analyze the impact of dividend on stock market price of Nepalese enterprises other specific objectives are as follows:

- To identify the effect of cash dividend on stock market price of Nepalese enterprises.

- To observe the effect of stock dividend on stock market price of Nepalese enterprises.

- To analyze the effect of return on assets, earnings per share and return on equity on stock market price of Nepalese enterprises.

The rest of the paper is organized as follows: Section 2 describes the population and sample of the study. The nature and sources of data is presented in Section 3. Model of the study is described in Section 4. Method of analysis is discussed in Section 5. Similarly, the result and discussion of the study is presented in Section 6. Finally, summary and conclusion are presented in Section 7.

\section{Population and sample}

The entire companies listed on Nepal Stock Exchange (NEPSE) till mid-July 2019 are the population of this study. All together there are 217 companies listed in NEPSE till mid-July 2019. Those companies are selected as samples which are paying either cash or stock dividend minimum three consecutive years during the study period. Out of these 217 companies 33 companies fulfilled this criterion and selected as sample. Thus this study is confined with 33 companies listed on NEPSE. List of sample companies are presented in Appendix-I.

\section{Nature and sources of data}

Secondary source of data only used to conduct this study. The annual report of sample companies is used to collect the required data for the study. Since this study is based on dividend paying companies only; unbalance panel data of 33 companies for the period of $2000 / 01$ to $2018 / 19$ is used to achieve the aim of the study.

\section{Model specification}

In this study market price of stock is used as dependent variable and cash dividend per share and stock dividend per share is used as explanatory variable. Furthermore, return on assets, earnings per share and return on equity is used as control variable. The impact of dividend on stock market price of Nepalese enterprises is analyzed using the following multivariate regression model.

$\mathrm{MPS}_{\text {it }}=\beta_{0}+\beta_{1} \mathrm{CD}_{\mathrm{it}}+\beta_{2} \mathrm{SD}_{\mathrm{it}}+\beta_{3} \mathrm{ROA}_{\mathrm{it}}+\beta_{4} \mathrm{EPS}_{\mathrm{it}}+\beta_{5} \mathrm{ROE}_{\mathrm{it}}+\varepsilon_{\mathrm{it}}$ Where, $M P S_{i t}=$ the market price of stock of firm $i$ for year $t$, $\beta_{i}=$ the coefficient of bank specific variable to be estimated, $\mathrm{CD}_{i t}=$ the cash dividend per share of firm $i$ for year $t$, $\mathrm{SD}_{i t}=$ the stock dividend per share of firm $i$ for year $t$, 
$R O A_{i t}=$ the return on assets of firm $i$ for year $t$,

$\mathrm{EPS}_{i t}=$ the stock earnings per share of firm $i$ for year $t$,

$\operatorname{ROE}_{i t}=$ the return on equity per share of firm $i$ for year $t$,

$\varepsilon_{i t}=$ the residual error term.

\section{Method of Analysis}

This study has used unbalanced panel data of 33 Nepalese enterprises for the period of 2001/02 to 2018/19 to analyze the impact of dividend on stock market price. STATA 12.0 software is used to analyze the data. To observe the nature and fact of the variables under the study; descriptive statistics has been calculated at first. In another section correlation among the variables under the study has been calculated. The correlation result showed the relationship between the stock market price and other variables of the study. Finally, multivariate regression model is estimated using Fixed Effect model. Fixed Effect model is selected on the basis of the result of Breusch and Pagan Lagrangian multiplier test for Pooped Regression model or Random Effect model and Hausman test for Random Effect model or Fixed Effect model.

\section{Result and Discussion}

Table 1 shows the descriptive statistics i. e. mean, standard deviation, minimum and maximum values of sample firm of the study. As evident from the result of table 1 a wide range of market price per share is found. It ranges from minimum Rs 91 to maximum Rs 6830 with mean value of Rs 1006.08.

\section{Table 1}

The table exhibits descriptive statistics (mean, standard deviation, minimum and maximum values) of the variable under the studied period of 2000/01 to 2018/19 for the 33 Nepalese enterprises listed in NEPSE commercial banks with 356 observations. MPS is market price of common stock at the end of year t. CD is cash dividend per share of at year $\mathrm{t}, \mathrm{SD}$ is stock dividend per share year $t$, ROA is return on assets at year $t$, which is obtained as net income divided by total assets.EPS is earning per share at year $t$, which is calculated by dividing net income by number of share outstanding and ROE is return on equity at year $t$, which is calculated by dividing net income available to common stock holder by shareholders' equity.

\begin{tabular}{lccccc}
\hline & Mean & Std. Deviation & Minimum & Maximum & $N$ \\
\hline MPS & 1006.08 & 986.43 & 91.00 & 6830 & 357 \\
CD & 12.71 & 20.46 & 0.00 & 130 & 357 \\
SD & 25.56 & 25.11 & 0.00 & 140 & 357 \\
ROA & 4.95 & 7.27 & -.12 & 59.49 & 357 \\
EPS & 39.41 & 30.46 & -3.00 & 175.84 & 357 \\
ROE & 18.90 & 9.32 & -2.78 & 85.16 & 357 \\
\hline
\end{tabular}


Similarly, wide range of cash dividend (CD) and stock dividend (SD) is also observed. As shown in table 1 the minimum value of cash dividend 0 percent and maximum value of 130 percent with mean value of 12.71 and minimum value of stock dividend 0 percent and maximum value of 140 percent with mean value of 12.56 percent is observed. Likewise, return on assets (ROA) showed mean value of 4.92 percent with minimum value of -0.12 percent and maximum value of 59.40 percent and earnings per share showed mean value of Rs 39.41 with minimum value of - Rs 3 and maximum value of Rs 175.84. Finally, another variable return on equity showed mean value of 18.90 percent with minimum value of -2.78 percent and maximum value of 85.16 percent. The result of descriptive statistics presented in table 1 confirms that the sample companies included in this study are quite diverse in term of their market price of share, cash dividend, stock dividend, return on assets, earnings per share and return on equity.

Table 2 presents the result of correlation analysis. Table 2 showed the value of correlation between 0.8249 to -0.0867 . Similarly, the correlation of market price per share (MPS) with cash dividend (CD), stock dividend (SD), earning per share (EPS) and return on equity (ROE) found positive and MPS showed negative correlation with return on assets (ROA). Likewise, the correlation between market price per share and cash dividend 0.4495 and correlation between stock dividend and market price per share 0.6082 is found. Furthermore, the value of correlation of MPS with ROA - 0.0596 and with EPS 0.5821 is observed. Finally, the value of correlation between MPS and ROE is found 0.4064 .

\section{Table 2: Correlation Results}

This table exhibits the correlation coefficients of market price of common stock (MPS), cash dividend $(\mathrm{CD})$, stock dividend (SD), return on assets (ROA), earning per share (EPS) and return on equity (ROE.)

\begin{tabular}{lrrrrrr}
\hline & $M P S$ & $C D$ & \multicolumn{1}{c}{ SD } & ROA & \multicolumn{1}{l}{ EPS } & \multicolumn{1}{l}{ ROE } \\
\hline MPS & 1.0000 & & & & & \\
CD & 0.4495 & 1.0000 & & & & \\
SD & 0.6082 & 0.6538 & 1.0000 & & & \\
ROA & -0.0596 & 0.0100 & -0.0867 & 1.0000 & & \\
EPS & 0.5821 & 0.8092 & 0.7199 & 0.2491 & 1.0000 & \\
ROE & 0.4064 & 0.5490 & 0.5505 & 0.2831 & 0.8249 & 1.0000 \\
\hline
\end{tabular}

\section{Model estimation}

This study has adopted Breusch and Pagan Lagrangian multiplier test for random effects to identify whether the data are fit for pooled or panel model and Hausman test to identify whether the data are fit for fixed effect model or random effect model. The result of Breusch and Pagan Lagrangian multiplier test and result of Hausman test is presented in table 3 and 4 respectively. As per the result of Breusch and Pagan Lagrangian multiplier test depicted in table 3 the value of chibar ${ }^{2}$ is 7.79 with probability value of 0.0025 . Since the value of $\operatorname{chibar}^{2}$ of 
is Breusch and Pagan Lagrangian multiplier test is significant at 5 percent level of significant it rejects the null hypothesis that the Pooled OLS model is appropriate.

Table 3: Result of Breusch and Pagan Lagrangian multiplier test

\begin{tabular}{|c|c|c|}
\hline & Var & $s d=\operatorname{sqrt}($ Var $)$ \\
\hline MPS & 973043.6 & 986.4297 \\
\hline E & 457403.4 & 676.316 \\
\hline$U$ & 55310.89 & 235.1827 \\
\hline Test: $\operatorname{Var}(u)=0$ & $\operatorname{chibar}^{2}(01)=7.79$ & 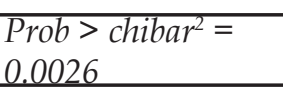 \\
\hline
\end{tabular}

Similarly, the result of Hausman test presented in table 4 shows the chi ${ }^{2}$ value of 27.91 with probability value of 0.000 . Since, the value of $\mathrm{chi}^{2}$ of Hausman test is significant at 1 percent level of significant it rejects the null hypothesis that Random Effect model is appropriate and accepts the alternative hypothesis that Fixed Effect model is appropriate. Thus, this study adopts the Fixed Effect model to analyze the effect of dividend on stock market price of Nepalese enterprises. The result of Fixed Effect model is presented in table 5.

Table 4: Result of Hausman Test

\begin{tabular}{|c|c|c|c|c|}
\hline & (b)Fixed Effect & (B)Random Effect & (b-B) Difference & $\operatorname{sqrt}\left(\operatorname{diag}\left(V \_b-V \_B\right)\right)$ \\
\hline$C D$ & -22.13848 & -18.38126 & -3.757227 & 1.20505 \\
\hline$S D$ & 6.158767 & 9.894665 & -3.735898 & 1.011956 \\
\hline$R O A$ & -33.73175 & -27.54948 & -6.18227 & 7.900699 \\
\hline EPS & 30.80225 & 29.18916 & 1.613088 & 1.93213 \\
\hline ROE & -33.43115 & -29.80756 & -3.623586 & 4.439243 \\
\hline \multicolumn{2}{|c|}{$x^{2}(5)=27.91$} & \multicolumn{3}{|c|}{ Prob> $x^{2}=0.0000$} \\
\hline
\end{tabular}

The result of table 5 depicts that there is significant impact of dividend on stock market price of common stock Nepalese enterprises after controlling return on assets (ROA), earnings per share (EPS) and return on equity (EOQ). The result of table 5 shows that there is significant negative impact of cash dividend (CD) on stock market price on Nepalese enterprises. The slope coefficient of CD is found -22.1385 with t-value of 5.64 which is significant at 1 percent level of significant. Similarly, the coefficient of SD is found 6.1588 with t-value of 2.23 which is significant at 5 percent level of significant. It indicates that increasing the cash dividend decrease the market price of common stock of Nepalese enterprises and increasing the stock dividend increases the market price of common stock of Nepalese enterprises.

Table 5: Average Slope Coefficients and Corresponding t-Value from Fixed-effects (within) regression

This table shows the regression results based on Fixed Effect Model of panel data of 33 Nepalese enterprises listed in NEPSE with 357 observations for the period of 2000/01 to 2018/19. 
The basic model is: $\mathrm{MPS}_{\mathrm{it}}=\beta_{0}+\beta_{1} \mathrm{CD}_{\mathrm{it}}+\beta_{2} \mathrm{SD}_{\mathrm{it}}+\beta_{3} \mathrm{ROA}_{\mathrm{it}}+\beta_{4} \mathrm{EPS}_{\mathrm{it}}+\beta_{5} \mathrm{ROE}_{\mathrm{it}}+\varepsilon_{\mathrm{it}}$

Dependent variable is the market price of common stock denoted as (MPS) ${ }_{\mathrm{it}}$ and independent variables are cash dividend (CD), stock dividend (SD), return on assets (ROA), earning per share (EPS) and return on equity (ROE).

\begin{tabular}{ccccc}
\hline Variable & Coefficient & Std. Error & t-statistics & p-value \\
\hline$C D$ & -22.1385 & 3.9224 & 5.64 & 0.000 \\
$S D$ & 6.1588 & 2.7680 & 2.23 & 0.027 \\
$R O A$ & -33.7318 & 10.9580 & -3.08 & 0.002 \\
$E P S$ & 30.8022 & 4.5998 & 6.70 & 0.000 \\
$R O E$ & -33.4311 & 9.3279 & -3.58 & 0.018 \\
Cons. & 713.6360 & 102.6071 & 6.96 & 0.000 \\
\hline$R^{2}:$ Overall $=0.4160$ & & $F(5,319)=20.62$ & \multicolumn{2}{c}{ Prob $>F=0.0000$} \\
F test that all ui $=0:$ & $F(32,319)=2.80$ & \multicolumn{2}{c}{ Prob $>F=0.0000$} \\
\hline
\end{tabular}

Furthermore, return on assets (ROA) and return on equity (ROE) shows significant negative impact on market price of common stock of Nepalese enterprises. The slope coefficient of ROA is found -33.7318 with $\mathrm{t}$-value of -3.08 which is significant at 1 percent level of significant and the slope coefficient of ROE is found -33.4311 with $t$-value of -3.85 which is significant at 5 percent level of significant. Finally, earnings per share (EPS) show the slope coefficient of 30.8022 with $\mathrm{t}$-value of 6.70 which is significant at 1 percent level of significant. It indicates that EPS has significant positive impact on market price of common stock of Nepalese enterprises.

Similarly, the result of table 5 shows the value of $\mathrm{R}^{2}$ (overall) 0.4160 which indicates that the stock market price is explained by 41.60 percent by explanatory variables of this study. Likewise, the value of $F(5,319) 20.62$ with probability value of 0.0000 indicates that the estimated Fixed Effect model is the best fitted model.

\section{Conclusion}

The impact of dividend on stock market price of Nepalese enterprises is analyzed in this paper. The stock market price of Nepalese enterprises is taken as dependent variable and cash dividend per share and stock dividend per share is used as explanatory variable. Likewise, return on assets, earnings per share and return on equity is used as control variables. Those companies are selected as sample which are listed on NEPSE and paid either cash dividend or stock dividend at least three consecutive years during the study period of 2000/01 to 20018/19. 33 Nepalese enterprises fulfilled this criterion and they are selected as sample. Since, this study is based on panel data; Breusch and Pagan Lagrangian multiplier test for Pooped Regression model or Random Effect model and Hausman test for Random Effect 
model or Fixed Effect model is used to select the appropriate model of regression. The result concluded that Fixed Effect model is appropriate model of the given data set of the study.

The fixed Effect model concludes that there is a significant impact of dividend on stock market of Nepalese enterprises. Further this study reveals that there is a significant negative impact of cash dividend and significant positive impact of stock dividend on stock market price of Nepalese enterprises. It indicates that Nepalese enterprises can increase their stock market price by increasing their stock dividend. Thus, the firm's management should try to increase stock dividend rather than cash dividend to increase their stock market price and their value of the firm. The result of this study is compactable with the result of Khan (2012) and Bhattarai (2016). They found that stock dividend has significant positive impact on stock market price.

\section{References}

Adesola, W. A., \& Okwong, A. E. (2009). An empirical study of dividend policy of quoted companies in Nigeria. Global Journal of Social Sciences, 8(1), 85-101.

Asghar, M., Shah, S. Z. A., Hamid, K., \& Suleman, M. T. (2011). Impact of dividend policy on stock price risk: Empirical evidence from equity market of Pakistan. Far East Journal of Psychology and Business, 4(1), 45-52.

Baral, R. K., \& Pradhan, A. (2018). Impact of dividend policy on share price of commercial bank in Nepal. International Research Journal of Management Science, 3, (1), 107-122.

Bhattarai, Y. R. (2016). Effect of dividend payment on stock prices of commercial banks in Nepal: Panel approach. Economic Journal of Development Issues, 21\&22 (1-2) 55-68.

Gordon, M. J. (1963). Optimal investment and financing policy. The Journal of Finance, 18(2), 264-272.

Hashemijoo, M., Mahdavi Ardekani, A., \& Younesi, N. (2012). The impact of dividend policy on share price volatility in the Malaysian stock market. Journal of Business Studies Quarterly, 4(1), 111-129.

Joshi, R. (2012). Effects of dividends on stock prices in Nepal. NRB Economic Review, 24(2), 61-75.

Khan, K. I. (2012). Effect of dividends on stock prices-A case of chemical and pharmaceutical industry of Pakistan. Management, 2(5), 141-148.

Margaretha, F. (2015). The effect of cash dividend, retained earnings, and stock price of manufacturing company listed in Indonesia Stock Exchange. The Winners, 16(1), 36-43.

Miller, M. H., \& Modigliani, F. (1961). Dividend policy, growth and the valuation of shares. The Journal of Business, 34(4), 411-433.

Pradhan, R. S. (2003). Effects of dividends on common stock prices: The Nepalese evidence. Research in Nepalese Finance, Kathmandu: Buddha Academics.

Rashid, A., \& Rahman, A. A. (2008). Dividend policy and stock price volatility: evidence from Bangladesh. The Journal of Applied Business and Economics, 8(4), 71-81.

Singh, N. P., \& Tandon, A. (2019). The effect of dividend policy on stock price: Evidence from the Indian Market. Asia-Pacific Journal of Management Research and Innovation, 15(1-2), 7-15. 


\section{Appendix - I}

\begin{tabular}{|c|c|c|c|}
\hline SN & COMPANY & Year selected for the study & $\begin{array}{l}\text { No. of } \\
\text { observation }\end{array}$ \\
\hline 1 & Asian Life Insurance Co. Limited & $2011,2012,2015$ to 2018 & 5 \\
\hline 2 & Everest Insurance Co. Ltd. & 2017 to 2019 & 3 \\
\hline 3 & Gurans Life Insurance Company Ltd. & 2012,2015 to 2017 & 4 \\
\hline 4 & Himalayan General Insurance Co. Ltd. & 2008 to 2010,2013 to 2017 & 8 \\
\hline 5 & Life Insurance Corporation (Nepal) Ltd. & 2008 to 2010,2012 to 2018 & 10 \\
\hline 6 & Lumbini General Insurance & 2009 to 2017,2019 & 10 \\
\hline 7 & National Life Insurance Co. Ltd. & $2006,2007,2010$ to 2018 & 11 \\
\hline 8 & NECO Insurance Ltd. & 2010 to 2012,2014 to 2018 & 8 \\
\hline 9 & Nepal Life Insurance Co. Ltd. & 2012 to 2018 & 7 \\
\hline 10 & Premier Insurance Co.(Nepal) Ltd. & $2007,2009,2010,2012,2014$ to 2018 & 9 \\
\hline 11 & Prime Life Insurance Company Limited & $2011,2012,2016$ to 2018 & 5 \\
\hline 12 & Sagarmatha Insurance Co. Ltd. & 2008 to 2010,2012 to $2016,2018,2019$ & 10 \\
\hline 13 & Agriculture Development Bank Limited & 2013 to 2019 & 7 \\
\hline 14 & Bank of Kathmandu Ltd. & 2002 to 2019 & 18 \\
\hline 15 & Citizen Bank International Limited & 2009 to 2019 & 11 \\
\hline 16 & Everest Bank Ltd. & 2002 to 2019 & 18 \\
\hline 17 & Himalayan Bank Ltd. & 2001 to 2019 & 19 \\
\hline 18 & Kumari Bank Limited & 2006 to 2019 & 14 \\
\hline 19 & Laxmi Bank Limited & 2008 to 2019 & 12 \\
\hline 20 & Machhapuchehhre Bank Ltd. & $2006,2008,2010,2014$ to 2019 & 9 \\
\hline 21 & NABIL Bank Ltd. & 2001 to 2019 & 19 \\
\hline 22 & Nepal Bangladesh Bank Limited & 2013 to 2019 & 7 \\
\hline 23 & Nepal Credit \& Com. Bank & $2012,2014,2015,2018,2019$ & 5 \\
\hline 24 & Nepal Investment Bank Ltd. & 2002 to 2019 & 18 \\
\hline 25 & Nepal SBI Bank Ltd. & $2001,2003,2006,2007,2009$ to 2019 & 14 \\
\hline 26 & NMB Bank Limited & $2007,2008,2010,2011,2013$ to 2019 & 11 \\
\hline 27 & Prime Commercial Bank Limited & 2010 to 2019 & 10 \\
\hline 28 & Sanima Bank Limited & 2009 to 2019 & 11 \\
\hline 29 & Siddhartha Bank Limited & 2007 to 2018 & 12 \\
\hline 30 & Standard Chartered Bank Ltd. & 2001 to 2019 & 19 \\
\hline 31 & Arun Valley Hydropower Dev Co Limited & 2014 to 2017,2019 & 5 \\
\hline 32 & Butawal Power Co. Ltd. & 2006 to 2019 & 14 \\
\hline \multirow[t]{2}{*}{33} & Chilime Hydro power Co. & 2006 to 2019 & 14 \\
\hline & Total observation & & 357 \\
\hline
\end{tabular}

